\title{
Akciğer Lezyonu Olan Hastaların Aspirasyonsuz İnce İğne Sitolojisi ile Tanısl: 10 Vaka Raporu ile Literatür Değerlendirmesi

\author{
Diagnosis of Patients With Lung Lesions by Fine Needle Nonaspiration \\ Cytology: Ten Cases Reports and Review of the Literature
}

\author{
${ }^{1,2}$ Şenay Y1lmaz, ${ }^{1,2}$ Güntülü Ak, ${ }^{2,3}$ Emine Dündar, ${ }^{1,2}$ Muzaffer Metintaş \\ ${ }^{1}$ Eskişehir Osmangazi Üniversitesi Tıp Fakültesi, Göğüs Hastalıkları Anabilim Dalı, \\ Eskişehir,Türkiye \\ ${ }^{2}$ Eskişehir Osmangazi Üniversitesi, Akciğer ve Plevra Kanserleri Uyg. ve Araştırma Merkezi, \\ Eskişehir,Türkiye \\ ${ }^{3}$ Eskişehir Osmangazi Üniversitesi Tıp Fakültesi, Patoloji Anabilim Dalı, Eskişehir,Türkiye
}

Özet: Periferik lenf nodu veya lezyona yönelik ince iğne aspirasyonunun (IİA) non invaziv bir inceleme yöntemi olduğu ve sitopatolojik tanı sağladığ önceki çalışmalarla gösterilmiştir. Burada geleneksel emici kuvvet uygulaması ile yapılan ince iğne aspirasyonu değil de aspirasyonsuz ince iğne sitolojisinin (AIIIS) kanser teşhisinde tanı ve evrelemeye katkısını vurgulamayı amaçladık. Akciğerde kitlesi olan 10 olguda periferik lenf nodu veya akciğerdeki periferal kitlelere uygulanan AIIIS'nin sonuçları değerlendirilmiştir.On hastanın (1'i kadın 9'u erkek), yaş ortalaması 59 (35-84) yıl idi. Periferik lenf nodu saptanan 7 hasta ile periferik yerleşimli akciğer lezyonu olan 3 hastaya AIİS yapıldı ve yaymalar değerlendirildi. Periferik lenf nodu ve periferik kitleden AIIIS yapılan 10 hastanın 2'si skuamoz hücreli karsinom, 4'ü küçük hücreli dışı akciğer karsinomu, diğer 4'ü ise malignite pozitif olarak tanı aldı. Malignite pozitif saptanan 4 hastadan 2'si bronkoskopi ile skuamoz hücreli karsinom ve küçük hücreli karsinom tanıları alırken 2 'si trucut biyopsi ile skuamoz hücreli karsinom ve lenfoma tanıları aldı. Lenf nodu ve periferik lezyondan yapılan AIİS tanının yanında akciğer kanserli hastalarda evreleme açısından da fayda sağladı. Sonuç olarak periferik olarak tümör veya tümör metastazına ulaşılabilen hastalarda AIIISS yapılması kolay ve etkin bir yöntemdir. Tanı yanında tümör non-rezektabilitesi değerlendirmede ve diğer ayırıcı tanılarda da faydalıdır. Bu nedenle AiİS lezyonu uygun olan ve özellikle invaziv işlemler açısından risk taşıyan hastalarda başlangıç noninvaziv tanı yöntemi olabilir. Sitoblok yöntemleriyle tanıyı artırmak mümkündür.

Anahtar Kelimeler: aspirasyonsuz ince iğne sitolojisi, periferik lenf nodu, periferik akciğer lezyonu

Yılmaz Ş. Ak G. Dündar E. Metintaş M. (2017). Akciğer Lezyonu Olan Hastaların Aspirasyonsuz İnce İğne Sitolojisi ile Tanısl: 10 Vaka Raporu ile Literatür Değerlendirmesi, Osmangazi Tip Dergisi 2017, 39(37-42):Doi:

\begin{abstract}
Fine needle aspiration (FNA) for peripheral lymph node or lesion was shown a non-invasive method that provides cytopathologic diagnosis with previous studies. We aimed to emphasize the contribution of fine needle nonaspiration cytology (FNNAC) not FNA performed by traditional suction force in diagnosis and staging of cancer. The results of FNNAC performed to the peripheral lymph nodes and lesions were evaluated in 10 cases with pulmonary mass. The mean age of 10 patients ( 1 was female, 9 were male) was 59 (35-84) years old. FNNAC was performed 7 of patients with peripheral lymph node, 3 of patients with peripheral lesion and, slides were evaluated. FNNAC was performed in 10 patients who 2 were diagnosed as squamous cell carcinoma (SQCLC), 4 were diagnosed as nonsmall cell lung carcinoma and 4 were diagnosed as positive malignancy. Two of 4 patients reported with positive malignancy were diagnosed as SQCLC and small cell carcinoma with bronchoscopy, while the other 2 were diagnosed as SQCLC and lenfoma with trucut biopsy. FNNAC performed on peripheral lymph nodes and lesions has provided benefits in terms of staging while confirmed the diagnosis. FNNAC is a simple and reliable method in patients whose tumors or tumor metastasis are available peripherally; in addition to tumor diagnosis it might be helpful for the evaluation of non-resectability and other differential diagnosis. FNNAC can be initial noninvasive diagnostic method especially in appropiate lesions and in patients with risk factors for invasive process. It might be possible to increase the diagnosis with sytobloc methods.
\end{abstract}

Keywords: fine needle nonaspiration cytology, peripheral lymph node, peripheral lung lesion

Yılmaz Ş. Ak G. Dündar E. Metintaş M. (2017). Diagnosis Of Patients With Lung Lesions By Fine Needle Nonaspiration Cytology: Ten Cases Reports And Review Of The Literature, Osmangazi Journal of Medicine 2017, 39 (37-42):Doi: 


\section{Giriş}

İnce iğne aspirasyonu periferik lenf nodları veya periferik lezyonlara uygulanan noninvaziv, etkili ve güvenilir bir inceleme yöntemi olup sitopatolojik tanı elde etmede faydalıdır. İnce iğne aspirasyon biyopsisi (İiAB)'nde aspirasyon materyali alınarak sitolojik inceleme ile lezyonun tanisı konulmaya çalış1lır. Özellikle $3 \mathrm{~cm}$ 'den küçük tümörlerde tan1 oran1 \%80 - 95'tir (1). IIIAB'ne alternatif olarak aspirasyonsuz ince iğne sitolojisi (AİIS) diğer isimleriyle 'cytopuncture' veya 'ince iğne kapiller örneklemesi' veya 'kapiller aspirasyon' veya 'ince iğne kapiller sitoloji' tekniği aktif emici kuvvet uygulamasını ortadan kaldıran bir ince iğne biyopsisi tekniği olup ilk kez 1982 yilında Santos ve Leiman tarafindan Fransa'da tiroid lezyonlarına uygulanmıştır $(2,3,4)$.

AIIIS akciğerde periferik kitle saptanan veya akciğerde kitle olup da periferik lenf nodu metastazı olan olgularda tıpk1 İIAB gibi lezyona direkt iğne sokularak, fakat emici kuvvet uygulamadan yapılan bir yöntemdir. Örneklenen materyal iğnenin içine kendiliğinden çekilir. İ̆gne içeriği daha sonra bir lam üzerine yayılarak veya formol içine püskürtülerek patolojik olarak yorumlanır. $\mathrm{Bu}$ teknik kolay uygulanımı yanında daha az kan içerdiğinden tanısal yeterliliği İİAB'ne göre daha fazladır (5). Periferik lenf nodu metastazlarına yönelik uygulanan AİIS, akciğer kanserinin evrelemesinde yol gösterici olduğu gibi baş-boyun tümörleri ve lenf bezi tümörlerinin ayırıcı tanısında da faydalı olabilmektedir. Benzer şekilde meme, kolorektal, pankreas gibi primer tümörlerin akciğere metastazlarında da radyolojik olarak saptanan periferik akciğer kitlelerine yönelik olarak da ayırıcı tanıda katkısı bulunmaktadır.
$\mathrm{Bu}$ çalışmada, periferik lenf nodu veya akciğerde periferal kitlesi olan 10 olguda, AIIIS tekniği kullanılarak, bu tekniğin teşhisin yanı sıra evrelemeye olan katkısının, literatür gözden geçirilerek vurgulanmas1 amaçlanmıştır.

\section{Gereç ve Yöntemler}

Çalışmada akciğerde periferik tümör tespit edilen veya tümörün metastazına ulaşılabilen toplam 10 olgu retrospektif olarak değerlendirildi. Araştırmaya başlamadan önce Eskişehir Osmangazi Üniversitesi Etik Kurul Başkanlığından etik kurul onayı alındı. Periferik lenf nodları palpe edilebilen veya periferik akciğer kitlelerine ultrason eşliğinde ulaşılabilen 10 olgunun işlem öncesi ayrıntılı anamnez, fizik muayene ve laboratuar değerlendirmeleri yapıldı. Periferik tümör veya tümörun metastazına ulaşılabilen hastalarda kitleden veya periferik lenf nodlarından ultrason eşliğinde AIIIS yapıldı. Alınan örnekler daha sonra sitolojik olarak değerlendirildi.

Aspirasyonsuz ince iğne sitolojisi uygulama yöntemi: Hasta lezyonun yerine göre pozisyon verilerek yatırılır veya oturtulur. Cild \%10 polyvidon iyot ile dezenfekte edilir, lokal anestezi uygulanır. Lezyon bir elin baş ve işaret parmakları arasında tespit edildikten sonra 21 gauge iğne enjektörsüz olarak lezyona sokulur. İğne lezyon içinde farklı yönlerde ve farklı açılarda çok az ileri geri hareket ettirilir. Enjektör olmadığından herhangi bir emici güç uygulanmaz. İğne çekildikten sonra hava ile doldurulmuş bir şırıngaya bağlanır ve 4-6 adet lam üzerine veya formol içine hücresel içerik ittirilir. Girişim bir kaç kez tekrarlanabilir. Ancak alınan örneğin yeterli olduğu düşünülüyor ise bir veya iki girişim de yeterli olabilir. Çalışmamızda en az 2 en fazla 4 girişim yapılmıştır (Resim 1a, 1b, 1c, 1d). 

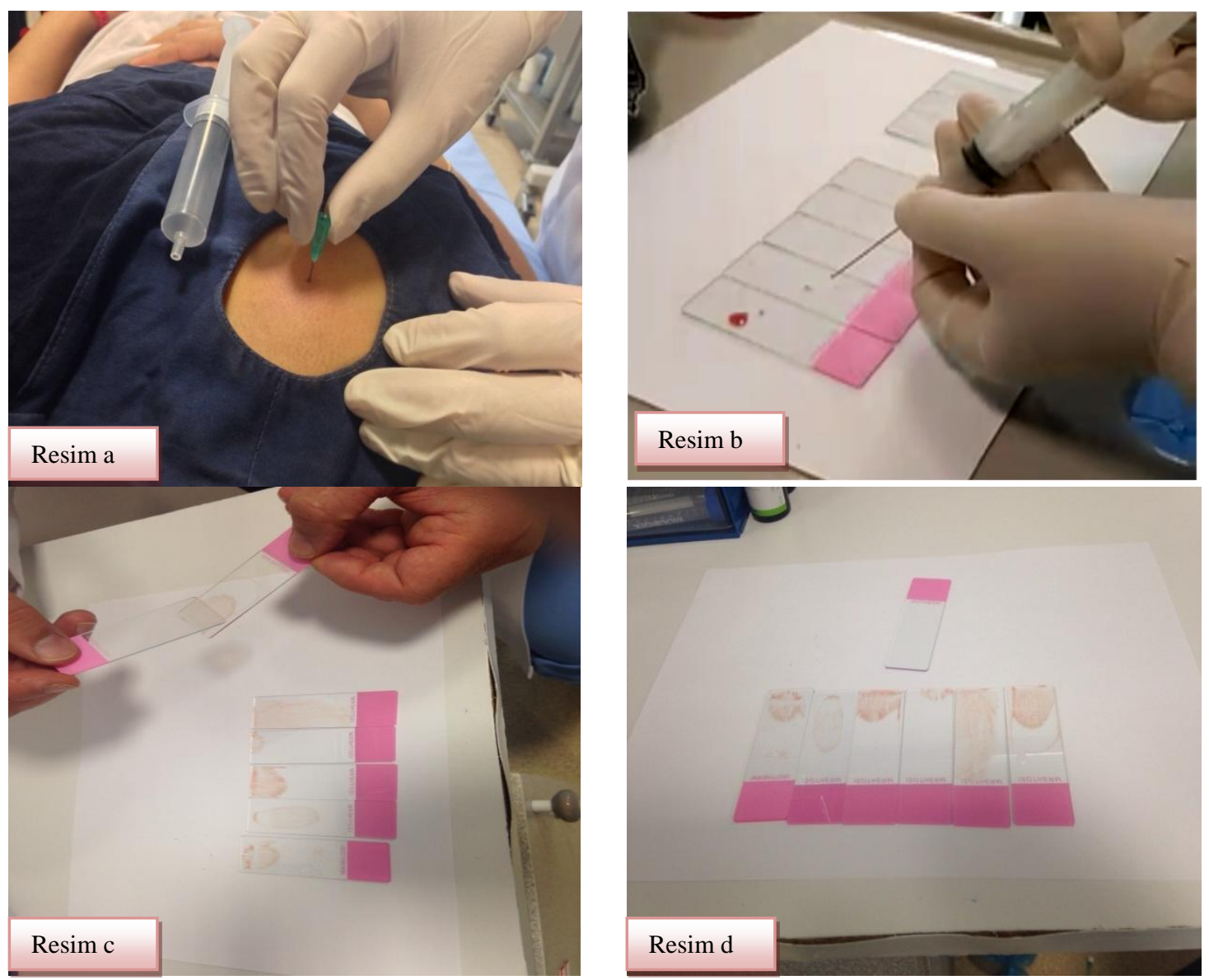

Resim 1 (a, b,c,d ) Aspirasyonsuz ince iğne sitolojisi uygulama yöntemi

Sitolojik değerlendirme: Yayma sonras lamlar havada kurutularak veya kurumadan \%96'lık alkol içinde patoloji laboratuvarına yollandi. Materyaller sitolopatoloji konusunda deneyimli patololog tarafindan değerlendirildi. Havada kurutulan direkt yaymalar rutin olarak May Grunwald Giemsa ile boyand. Lama yayılmadan patoloji laboratuvarına ulaştırılan Sıvı örnekleri sitosantrifüj sonrası yayma haline getirildi ve giemsa ile pap boyaları uyguland. Yayma sonrası tüpte veya enjektörde kalan materyal ayrı bir alanda çöktürülerek hücre bloğu haline getirildi ve formolde tespit edilerek parafine gömüldü. Hazırlanan parafin bloklardan $5 \mu \mathrm{m}$ kalınlığında kesitler alınarak dokular gibi Hematoksilen\&Eozin ile boyand. Taniya yardıme1 immunohistokimyasal çalışmalar bu hücre bloğu örneklerine uygulandı. Örneğin Tablo 1'de belirtilen 9 nolu vakaya ait histopatolojik ve immunohistokimyasal bulgular Resim 2'de gösterilmiştir.

\section{Bulgular}

Akciğerde periferik kitle veya periferik lenf nodu metastazı saptanan 1'i kadın 9'u erkek toplam 10 olgu değerlendirmeye alındı. Olguların yaş aralığı 35-84 yıl iken yaş ortalamas1 59 yıl idi. Kadın olgunun sigara öyküsü yokken erkek olguların tamamı sigara içicisiydi ve ortalama sigara içme süresi 42 yıl idi. Periferik lenf nodu tespit edilen 7 olgunun 6'sında supraklavikuler lenf noduna, 1'inde ise inguinal lenf noduna yönelik AIIIS yapıldı. Periferik yerleşimli akciğer lezyonu olan 3 hastaya AIIIS yapıldı ve yaymalar değerlendirildi. Periferik lenf nodu ve periferik kitleden AIIIS yapılan 10 hastanın

2'si skuamoz hücreli karsinom, 4'ü küçük hücreli dışı akciğer karsinomu, diğer 4'ü ise malignite pozitif olarak tanı aldı. Malignite pozitif saptanan 4 hastadan 2'si bronkoskopi ile skuamoz hücreli karsinom ve küçük hücreli karsinom tanıları alırken 2'si trucut biyopsi ile skuamoz hücreli karsinom ve lenfoma tanıları aldı (Tablo 1). Akciğer kanseri tespit edilen olguların 1'i evre 3A, 4'ü 
evre 3B, 3'ü evre 4 olarak evrelendirilirken 1'i AİSS sonucu ile nüks kabul edildi ve tek kadın olgu ise lenfoma tanısı alarak ilgili bölüme tedavi amaçlı yönlendirildi. Lenf nodu ve periferik lezyondan yapılan Aİ̈S, tanının yanında evreleme ve nükslerin tespiti açısından da fayda sağladı.

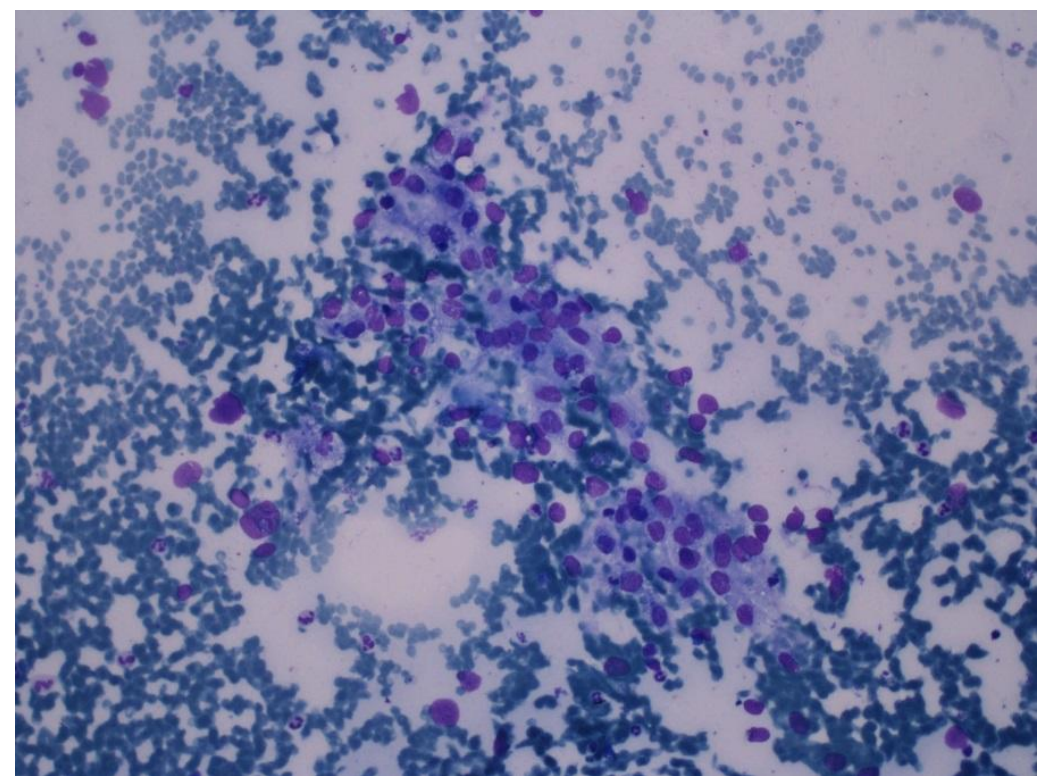

Resim 2. Sol supraklaviküler lenf nodundan yapılan aspirasyon biyopsisinde kan elemanları arasında grup oluşturma ĕğiliminde iri, pleomorfik nükleuslu hücreler izlenmektedir (Giemsa x 200)

\section{Tablo 1.}

AIIIS sonrası ve ana tanı yöntemi sonrası olguların histolojik tanıları LN: Lenf nodu, AIIIS: Aspirasyonsuz ince iğne sitolojisi, SHK: Skuamöz hücreli karsinom, KHDK: Küçük hücreli dışı karsinom, AK: Adenokarsinom, KHK: Kü̧̈ük hücreli karsinom, EBUS: Endobronşial Ultrasonografi

\begin{tabular}{|c|c|c|c|c|}
\hline $\begin{array}{c}\text { Olgu } \\
\text { numaras1 }\end{array}$ & $\begin{array}{c}\text { AİİS yapılan } \\
\text { doku }\end{array}$ & $\begin{array}{c}\text { AİIS } \\
\text { histolojik tanıs1 }\end{array}$ & $\begin{array}{c}\text { Ana } \\
\text { tanı yöntemi }\end{array}$ & $\begin{array}{l}\text { Ana tan1 yöntemi } \\
\text { histolojik tanıs }\end{array}$ \\
\hline 1 & $\begin{array}{l}\text { Periferik } \\
\text { lezyon }\end{array}$ & SHK & Trucut biyopsi & SHK \\
\hline 2 & $\begin{array}{c}\text { Supraklavikuler } \\
\text { LN }\end{array}$ & Malignite pozitif & Trucut biyopsi & SHK \\
\hline 3 & $\begin{array}{c}\text { Supraklavikuler } \\
\text { LN }\end{array}$ & KHDK & Bronş biyopsisi & AK \\
\hline 4 & $\begin{array}{c}\text { Supraklavikuler } \\
\text { LN }\end{array}$ & SHK & Bronş biyopsisi & SHK \\
\hline 5 & İnguinal LN & Malignite pozitif & Bronş biyopsisi & SHK \\
\hline 6 & $\begin{array}{c}\text { Supraklavikuler } \\
\text { LN }\end{array}$ & & $\begin{array}{c}\text { Supraklavikuler } \\
\text { LN AİIS }\end{array}$ & KHDK \\
\hline 7 & $\begin{array}{l}\text { Periferik } \\
\text { lezyon }\end{array}$ & Malignite pozitif & Trucut biyopsi & Lenfoma \\
\hline 8 & $\begin{array}{l}\text { Periferik } \\
\text { lezyon }\end{array}$ & KHDK & Trucut biyopsi & SHK \\
\hline 9 & $\begin{array}{c}\text { Supraklavikuler } \\
\text { LN }\end{array}$ & KHDK & Bronş biyopsisi & SHK \\
\hline 10 & $\begin{array}{c}\text { Supraklavikuler } \\
\text { LN } \\
\end{array}$ & Malignite pozitif & $\begin{array}{c}\text { EBUS-lenf nodu } \\
\text { biyopsisi }\end{array}$ & KHK \\
\hline
\end{tabular}




\section{Tartışma}

İ̇AB geniş kullanımı ile daha çok tiroid lezyonlarında birçok klinisyen tarafından uygulanan noninvaziv tanısal bir yöntemdir. Ancak tiroid veya diğer vasküler organlardan elde edilen materyallerin hemorajik olması nedeniyle alternatif olarak AIIIS diğer isimleriyle 'cytopuncture', ince iğne kapiller örneklemesi' veya 'kapiller aspirasyon' veya 'ince iğne kapiller sitoloji' tekniği ilk kez Fransa'da 1982 yilında Santos ve Leiben tarafından tiroid lezyonlarında, Maier ve ark. tarafından yüzeyel lezyonlarda, Dey ve ark. tarafindan ise sonrasinda transtorasik ve intraabdominal lezyonlarda uygulanmıştır (2, 6, 7). AIIIS, spontan kapiller harekete bağl1 olarak hücrelerin iğne deliğinde toplanmasını sağlar. Böylece boyun, meme, cilt ve cilt altı dokularda uygulanımı ve kontrolü kolay bir yöntem olarak tercih edilmektedir.

Çalışmamızda periferik lenf nodları ve akciğerdeki periferik kitlelere AIİS tekniği uygulanmış olup AIIIS'nin kısa sürede tanı koyma, tanıyı doğrulama ve evrelemeye katkı sağlamadaki önemi vurgulanmıştır. Çoğu çalışmada İIAB ve AIİS tekniklerinin tanısal etkinliği tiroid lezyonlarında çalışılarak karşılaştırılmıştır $(5,8,9)$. Akciğer kanserinde ise supraklavikuler lenf nodlarına uygulanan AIIIS ile ilgili çok sayıda çalışma mevcuttur $(10,11,12,13)$. Biz de bu çalışmada hem akciğerde kitlesi olup uzak metastaz yapan periferal lenf nodlarına hem de periferik akciğer kitlelerine direkt uygulanan AIİS 'nin sonuçlarını tartıştık.

Palpe edilebilen supraklavikuler lenf nodu olan olgulara veya nonpalpabl olan olgulara da ultrason yapmak suretiyle AIİS uygulaması tek işlemde patolojik tanı ve eş zamanlı evreleme olanağı sağlamaktadır. Olgularımızın 6'sına supraklavikuler lenf nodundan, l'ine de inguinal lenf nodundan AIIIS yapılmıştır. Lenf nodu örneklemesi 3 olguda küçük hücreli dişı karsinom, 3 olguda malignite pozitif, 1 olguda ise skuamöz hücreli karsinom olarak raporlanmıştır. Küçük hücreli dişı karsinom tanısı alan 3 olgunun 2'si fiberoptik bronkoskopik bronş biyopsisi ile skuamöz hücreli karsinom ve adenokarsinom tanısı alırken $1^{\prime} \mathrm{i}$ de trucut biyopsi ile skuamöz hücreli karsinom tanıs1 almıştır. Malignite pozitif olan 3 olgunun 1'i bronş biyopsisi ile küçük hücreli karsinom, 1'i trucut biyopsi ile lenfoma tanısı alırken 1'i de bronş biyopsisi ile küçük hücreli karsinom tanısı almıştır (Tablo 1). Sonuçlarımız lenf nodu örneklemesinin hem tanıyı koymada hem de evrelemede katkısını bir kez daha göstermektedir.

Literatürde benzer yöntemle akciğger lezyonlarının örneklendiği bir çalışma bulunmamaktadır. $\mathrm{Bu}$ nedenle sonuçlarımızı bu anlamda değerlendiremedik. Bilindiği üzere İIAB toraksın periferik yerleşim gösteren lezyonlarının tanısında kullanılan etkin ve güvenilir bir tanı yöntemidir $(14,15)$. Bazı çalışmalarda BT eşliğinde yapılan İİA ile akciğerdeki lezyonlardan sitolojik tanısal doğruluk oranı \%92-95 olarak bildirilmiştir $(14,16)$. Çalışmamızda kullandığımız yöntem tiroid lezyonları için kullanılmaktadır. Tiroid lezyonlarında yapılan bir çalışmada AİISS tanı oranı, İIAB tanı oranı ile benzer bulunmuştur (8). Biz çalışmamızda periferik kitle saptanan 3 olguya İIAB yerine AIIIS uyguladik ve bu olguların 1'i küçük hücreli dışı karsinom, 1'i skuamöz hücreli karsinom ve diğeri de malignite pozitif olarak raporland1. Bu sonuç da akciğerde periferik kitlelerde aynen İ̇AB'de olduğu gibi AIIIS'nin de tanıda fayda sağladığını desteklemektedir. Çalışmamızda olgu sayısı az olmakla beraber tüm hastalarda tanıya ulaşılmıştır.

AIIIS daha konsantre, daha az travmatize ve kan pihtısının oluşturduğu bozulmanın daha az olduğu bir yöntemdir (2). Klinik uygulamada bu yöntemi ağrı ya da rahatsılılı hissi ile tolere edemeyen, komplikasyonu olan hiçbir olgumuz olmadı. Ayrıca bu yöntem tekniği uygulayan hekim için kolay olması ve enjektörsüz olmasından dolayı da lezyonun daha iyi hissedilip daha kolay hareketler yapılarak örnekleme yapılması açısından da fayda sağlamıştır. İğnenin parmaklar arasında sensör görevi görerek doğrudan lezyona yönelmesi bunu açıklamaktadır. Bazı çalışmalar bu tekniğin geleneksel emici kuvvet uygulaması ile yapılan İIAB'ne göre örnek elde etmedeki üstünlügünü ortaya koyarken bazıları da ikisi arasında sitolojik olarak anlamlı fark saptanmamakla beraber daha az travmatik olması, daha az kan pihtısı içermesi ve daha kolay manuple edilmesi anlamında üstünlüğünü vurgulamıştır $(5,17$, 18, 19). Olgularımızdan elde ettiğimiz sonuçlar da bu çalışmaları destekler yöndedir. Olgularımızın sayısının az olması ve sitolojik olarak rutin alışılagelmiş yayma yönteminin kullanılıyor olması çalışmanın zayıf yönleriyken popüler bir yöntem olan Aİ̇S'nin uygulanırlığının arttırılmasını vurgulaması 
açısından değerlidir. Bu nedenle olgularımızın sayısını arttırarak ve sitoblok yöntemi kullanarak yeni çalışmalar hedeflemekteyiz.

\section{Sonuç}

Sonuç olarak periferik olarak tümör veya tümör metastazına ulaşılabilen hastalarda AIIIS yapılması kolay ve etkin bir yöntemdir;

\section{Kaynaklar}

1. Spread, I. (1997). American Thoracic Society/European Respiratory Society. Am J Respir Crit Care Med, 156, 320-332.

2. Santos, J. E., \& Leiman, G. (1987). Nonaspiration fine needle cytology. Application of a new technique to nodular thyroid disease. Acta cytologica, 32(3), 353-356.

3. Martin and Ellis 1926 cited in Kline, T. S. (1981). Handbook of fine needle aspiration biopsy cytology. CV Mosby.

4. Pothier, D. D., \& Narula, A. A. (2006). Should we apply suction during fine needle cytology of thyroid lesions? A systematic review and metaanalysis. The Annals of The Royal College of Surgeons of England, 88(7), 643-645.

5. Ramachandra, L., Kudva, R., Rao, B. A., \& Agrawal, S. (2011). A comparative study of fine needle aspiration cytology (FNAC) and fine needle non-aspiration cytology (FNNAC) technique in lesions of thyroid gland. Indian Journal of Surgery, 73(4), 287-290.

6. Mair, S., Dunbar, F., Becker, P. J., \& Du Plessis, W. (1988). Fine needle cytology--is aspiration suction necessary? A study of 100 masses in various sites. Acta cytologica, 33(6), 809-813.

7. Dey, P., \& Ray, R. (1994). Fine needle sampling without suction in intraabdominal lesions: comparison with fine needle aspiration. Acta cytologica, 38(3), 495.

8. Malik, N. P., Jain, M., Sharma, C. V., Verma, N., Singh, A., Singh, G., \& Kumar, S. (2013). Comparison of aspiration versus non-aspiration technique of cytodiagnosis in thyroid lesions. Journal, Indian Academy of Clinical Medicine, 14(1), 20-22.

9. McElvanna, K., Pyper, P. C., \& Miller, K. (2009). A comparison of fine-needle aspiration versus nonaspiration cytology of thyroid nodules. The Internet Journal of Surgery, 25(2).

10. Ozkan, G., Tutar, M., Bayram, M., Bakan, D., Gür, A., \& Camsari, G. (2009). The impact of ultrasonography-guided fine needle aspiration of no palpable supraclavicular lymph nodes on diagnosis and staging in advanced lung cancer. Tuberk Toraks, 57(2), 186-191. tanı yanında tümör non-rezektabilitesini değerlendirmede ve diğer ayırıcı tanılarda da yol gösterici olabilir. Hasta sayısı yetersiz olmasına rağmen klinik ve radyolojik olarak ileri evre akciğer kanseri düşünülen periferik lenf nodu veya periferik kitle saptanan olgularda AIİS başlangıç noninvaziv tanı yöntemi olabilir. Sitoblok yöntemleriyle tanıyı artırmak mümkündür.

11. van Overhagen, H., Brakel, K., Heijenbrok, M. W., van Kasteren, J. H., van de Moosdijk, C. N., Roldaan, A. C., ... \& Hansen, B. E. (2004). Metastases in Supraclavicular Lymph Nodes in Lung Cancer: Assessment with Palpation, US, and CT 1. Radiology, 232(1), 75-80.

12. Tian, H. Y., Xu, D., Liu, J. P., Mao, W. M., Chen, L. Y., Yang, C., ... \& Shi, K. Y. (2015). Contribution of ultrasound-guided fine-needle aspiration cell blocks of metastatic supraclavicular lymph nodes to the diagnosis of lung cancer. Journal of cancer research and therapeutics, 11(8), 234.

13. Awwad, A., Tiwari, S., Sovani, V., Baldwin, D. R., \& Kumaran, M. (2015). Reliable EGFR mutation testing in ultrasound-guided supraclavicular lymph node fine-needle aspirates: a cohort study with diagnostic performance analysis. BMJ open respiratory research, 2(1), $\mathrm{e} 000075$.

14. Mondal, A., \& Pradhan, M. C. (1991). Role of percutaneous fine needle aspiration cytology (FNAC) in detection of lung, pleural and mediastinal tumours--a study of 162 cases. Indian journal of pathology \& microbiology, 34(4), 253258.

15. Huq, M. H., Talukder, S. I., Haque, M. A., Sarker, C. B., Saleh, A. F., \& Debnath, C. R. (2004). Role of fine needle aspiration cytology in the diagnosis of pulmonary lesions. Mymensingh medical journal: $M M J, 13(1), 16-19$.

16. Madan, M., \& Bannur, H. (2010). Evaluation of fine needle aspiration cytology in the diagnosis of lung lesions. Turk J Pathol, 26, 1-6.

17. Koirala, S. (2014). Comparative study of aspiration and non-aspiration cytology of palpable breast lumps and correlation with histopathology. Journal of Pathology of Nepal, 4(8), 639-643.

18. Baksh, S., Masih, K., Singh, S., \& Das, S. (2004). Diagnostic utility of fine needle non-aspiration cytology versus fine needle aspiration cytology in breast masses. Indian journal of pathology \& microbiology, 47(3), 319-321.

19. Pathak, S. S. (2015). Non-aspiration cytology of breast lumps: a comparative study. Annals of Applied Bio-Sciences, 2(3), A60-65. 